\title{
Impact of COVID-19 on Food Systems and Rural Livelihoods in Zimbabwe
}

\author{
COVID-19 Country Report - September $2020 \quad$ Prepared by Vine Mutyasira
}

\section{Introduction}

COVID-19 has undoubtedly affected lives and livelihoods across the globe. In Zimbabwe, preliminary indications point to a worsening economic situation in a country already facing macroeconomic challenges, particularly in rural communities where most households depend on agriculture. National lockdown and movement restrictions have affected agricultural activities as well as access to markets and farming inputs.

\section{Context}

To get a clear picture of the impacts of COVID-19 on food production systems, supply chains and general livelihoods in the rural communities, APRA implemented a rapid assessment in Mvurwi and Concession Areas of Mazowe District. We interviewed 107 farming households (18 female- and 89 maleheaded) and five key informants representing community leaders, farmer representatives and extension officers. The APRA COVID-19 data collection will be carried out over three rounds. This report presents insights obtained from the first round implemented during late June/early July 2020.

\section{Health and disease}

All respondents indicated awareness of COVID-19 and that they were following recommended safety measures to prevent risk of exposure and spread of the virus. They had been sensitised by Ministry of Health awareness campaigns, as well as by information broadcasts via radio and TV. Most respondents (96\%) reported that they were still able to access local health clinics during the pandemic because the virus did not spread much outside Harare and Bulawayo. Only 3\% of respondents reported knowing about confirmed COVID-19 cases outside their villages.

\section{Effects on farming, labour and marketing}

Lockdown restrictions have disrupted agricultural marketing activities, reduced access to hired labour services and production inputs, and increased the cost of tillage services. About 58\% of respondents reported that farming activities were negatively affected by the COVID-19 crisis, while 42\% further indicated that their participation in other businesses and household enterprises was reduced.

Some $45 \%$ of respondents reported that they were unable to hire labour services for their farming activities, while $48 \%$ stated that the cost of hiring day or casual labour had gone up. COVID-19 also significantly affected households' ability to sell their produce as a result of transportation challenges and the closing of food outlets. As a result, $87 \%$ of respondents noted that farmgate sales had reduced, $81 \%$ observed that sales through district and regional markets were severely affected, $87 \%$ experienced a drop in local market sales, and 31\% noted that their ability to sell produce through national markets was curtailed. The majority of

\section{Key findings}

- Communities were generally aware of the COVID-19 pandemic and had been observing recommended health protocols, including wearing masks and social distancing.

- Besides awareness campaigns and lockdown enforcement, government support to communities had been very limited.

- COVID-19 had worsened the livelihoods of rural communities who largely depend on agricultural activities by disrupting their production, marketing and other activities that bring income.

- The majority of households (86\%) were not able to access off-farm work to augment dwindling agricultural incomes after the start of the COVID-19 crisis.

- Access to essential farm inputs and support services had been worsened by disruptions in supply chains and increasing transportation costs.

- Most households (84\%) reported a rise in the cost of living and a worsening food security situation.

- The majority of respondents (64\%) reported that they did not receive any form of assistance; $27 \%$ received support from family and friends, 15\% from government programmes and $4 \%$ from local village organisations.

"Some egg producers have had to sell their layers because they failed to secure feed concentrates for their birds. A lady here slaughtered her entire flock of layers and sold them for meat so she could cut her losses." - Extension officer, Mvurwi, Mashonaland Central

respondents $(71 \%)$ reported an increase in the price of transport due to lockdown measures. Restrictions also severely affected the ability of buyers and brokers to visit communities to purchase produce directly from farmers, according to $94 \%$ of respondents.

\section{Availability of services for agricultural production}

Due to the COVID-19 restrictions, local agro-dealers have been running low on supplies leading some to close shop. Consequently, $88 \%$ of respondents noted that the price of farm inputs, such as seeds, fertilisers, agrochemicals, and veterinary drugs had risen. About $70 \%$ of respondents stated that the availability of extension services had reduced, while $64 \%$ reported that the cost of tillage services had gone up significantly. This was compounded by the ongoing fuel crisis, epitomised by erratic supplies and most service stations only selling fuel in US dollars. 
Respondents were also asked to give an assessment of their overall welfare situation before and after COVID-19 using a 9-step ladder approach, where those on Step 1, the lowest step, feel totally unable to change their lives, and those on Step 9, the highest step, believe they have full control over their lives. Before the crisis, $73 \%$ of households rated themselves as being on Steps 5-9, while afterwards only $17 \%$ placed themselves on those levels. As such, the results indicate that COVID-19 has worsened many households' welfare situations.

\section{Food and nutrition security}

- The disruption of production activities and dissipation of livelihoods activities means that COVID-19 has negatively affected the availability and prices of food items in local markets.

- Overall, $84 \%$ of respondents said that the cost of living had gone up. Some $74 \%$ stated that they were unable to eat healthy and nutritious food, while $82 \%$ resorted to eating only a few kinds of foods, due to a lack of money and other resources.

Figure 1: Food security situation due to COVID-19

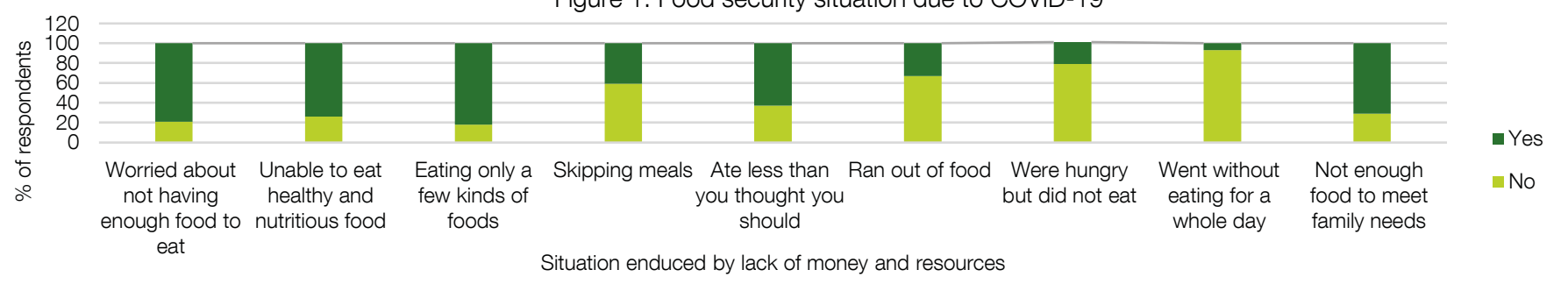

\section{Responses to the threat of COVID-19}

- The national lockdown restricted inter-city travel and informal sector activities, and banned social gatherings including at churches and clubs, except for a few essential services.

- At the community level, 94\% and 97\% of respondents observed that movement within and outside the village was restricted, respectively.

- About $87 \%$ of respondents encountered incidences in which family and friends from outside the village were prevented from visiting, particularly during the early stages of the outbreak when many people were returning from the cities. There were also incidences of returning residents escaping quarantine facilities. As a result, community leaders instigated stringent measures where families had to report new visitors to local authorities.

- $92 \%$ of informants reported that the number of traders into local communities had reduced significantly.
- School closures presented new challenges for parents in terms of how to manage their children's continued learning. Households reported assigning their children additional responsibilities for housework (77\% girls/61\% boys) and farm work (58\% girls/60\% boys). Nevertheless, many children also continued to do schoolwork at home $(75 \%$ girls/69\% boys), although roughly a third were reported as being idle during this period (Fig. 2).

Figure 2: Children's occupation during CŌVID-19

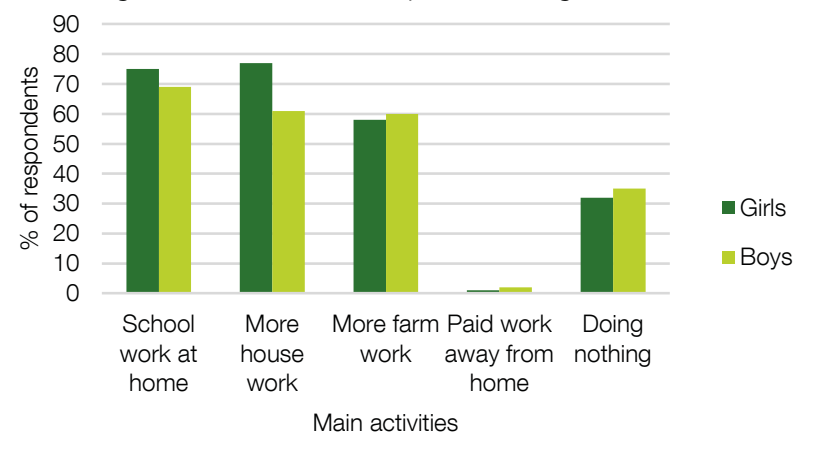
credited, the work is not used for commercial purposes, and no modifications or adaptations are made.

If you use the work, we ask that you reference the APRA website (www.future-agricultures.org/apra) and send a copy of the work or a link to its use online to the following address for our archive: APRA, Future Agricultures, University of Sussex, Brighton BN1 9RE, UK (apra@ids.ac.uk)

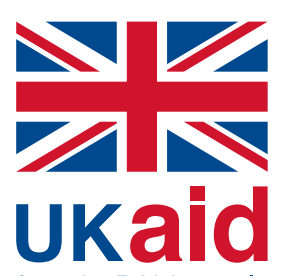

from the British people
This report is funded with UK aid from the UK government (Foreign, Commonwealth \& Development Office - FCDO, formerly DFID). The opinions are the authors' and do not necessarily reflect the views or policies of IDS or the UK government. 